\title{
USING SUBJECTIVE EQUIVALENCE SCALES TO ANALYZE POVERTY IN POLAND ${ }^{1}$
}

The subjective equivalence scale for Poland in 2010 is estimated using the Polish Household Budget Survey. The scale increases consistently with household size, thus showing larger economies of scale than would be shown if the OECD approach was used. We compare the poverty rates based on the subjective scale with those obtained using expert approach. The overall poverty rates are not much different, but the choice of weighting methods leads to a significantly different distribution of poverty when different types of households are considered. In particular, according to the subjective approach, the one-person households are mostly at risk of financial poverty. This is opposite to the OECD approach, according to which larger households are more at risk. The results are consistent with those for the euro zone countries discussed in Bishop et al. (2014).

Keywords: subjective equivalence scale, Income Evaluation Question, poverty

JEL Classifications: D63, I32, P46

DOI: $10.15611 /$ aoe.2018.2.09

\section{INTRODUCTION}

Equivalence scales allow comparing inter-household welfare and/or the well-being of units differing in size. They are frequently used when discussing the cost of having children, as well as when measuring social welfare and economic inequality. The scales are calculated as an intermediate step in poverty analyses, making them part of the public debate on poverty and income disparity issues. During the parliamentary campaigns in Poland in 2007 and 2011, all the major parties proposed polices targeting large families since they were perceived as the ones needing special assistance at the most. This claim was justified by referring to the poverty statistics based on the modified OECD equivalence scale published by Eurostat and the Polish Central Statistical Office (CSO). For example, during the 2011 Parliamentary election campaign, Jarosław Kaczyński (the

\footnotetext{
* Institute of Economics, the Polish Academy of Sciences

${ }^{1}$ This work was supported by the Polish National Science Centre (NCN) under Grant No. DEC-2013/09/B/HS4/01923.
} 
opposition leader) said that "If you look at the statistics of people living below the poverty line, the share of families with many children in this group is incomparably greater than that of families in society in general. The large number of children is the main cause that leads a family to a difficult or very difficult financial situation."

The current Eurostat data have revealed that in Poland in 2013 the at-risk of poverty rate was $37.3 \%$ among parents with three or more children, $17.2 \%$ for parents with two children, and $22.0 \%$ for one-person households. The same pattern, where larger households had the highest risk of poverty rate, was also observed in other years, for example the respective values for 2010 were: $32.8 \%, 19.8 \%$ and $24.5 \%$.

The choice of the equivalence scale can significantly change the results of any poverty analysis based on a poverty line definition (Buhman et al. 1998, Bollinger et al. 2012, Bishop et al. 2014, de Ree et al. 2013). The main goal of the research is to compare the levels and the structure of subjective poverty rates according to family types with the rates calculated using the OECD modified scale. Additionally, we make statements about the extent of economy of scale in household size and the marginal cost of a child. Based on literature survey and earlier results for Poland, we may hypothesize that a subjective approach to poverty leads to bigger poverty rates among households with a small number of members and lower rates among large households. Our results confirm such expectations since poverty rates for large households are lower for the subjective scale than for the OECD one, and the opposite is true for small households that have a higher risk of poverty under the traditional method. This is an important result since differences in structures of poverty should lead to different policy suggestions. For example, a policy based on a subjective approach would allocate more resources to single-adult and one-child households instead of to larger ones.

Despite decreasing rate of relative poverty, the rate of extreme poverty in Poland has not changed significantly for the last couple of years. This makes the issues discussed in the paper highly relevant. There is a long history of applying a subjective approach to income weighting for the purpose of poverty analysis in Poland. These works were already initiated in the 1990s by Podgórski (1990, 1991, 1994), who showed much flatter equivalence scales implied by the subjective approach than the commonly used OECD scales. More recent works in this field are those of Dudek (2009), Dudek (2012), Dudek and Landmesser (2012) and Ulman (2012). All of them show the potential big discrepancy between the "official" approach embodied in 
the Eurostat and GUS method of calculating relative poverty and the alternative measures based on the subjective approach.

The value of information about the structure of poverty is unquestionable. The poverty rates that are most commonly discussed are based on the OECD scale that has no theoretical justification, therefore other scales may also be used to get a more diverse picture of poverty. The goal of this paper is to check the results of using subjective equivalence scales instead of the OECD scale for calculations of poverty rates. On the grounds of the previous results we may expect that it brings significant changes to the conclusion on the household structure of relative poverty, showing more poverty among small units and less among those with larger numbers of people.

Following the introduction, Section 2 describes the approach used for estimating subjective equivalence scales. Section 3 provides information on data and model specification. The results are given in Section 4. The last section summarises these results and contains the final conclusion.

\section{ALTERNATIVE APPROCHES TO EQUIVALENCE SCALES}

The OCED equivalence scale was proposed in 1982 with the weights: 1 for the first adult, 0.7 for the second and consecutive adult and 0.5 for a child. It was modified in 1994, applied in Eurostat poverty statistics and by national statistical offices. The OECD modified equivalence scale assumes three weights: 1 for the first adult, 0.5 for the second and consecutive adult and 0.3 for a child. A child is defined as a person aged under 14 . With these assumptions a single person household with PLN 1,000 is considered to achieve the same level of "well-being" as a two-adult household with PLN 1,500 and a household consisting of a single parent and one child with PLN 1,300. It is assumed that each consecutive child increases the amount necessary to keep their well-being unchanged. For example, if a childless couple's income is PLN 1,500 PLN, then PLN 300 more is needed in order to keep the same level of well-being after the first child is born. An additional PLN 300 would be necessary if a second child was to be added to the family. Therefore, PLN 1,500 for a couple without children, PLN 1,800 for a couple with a one child, and PLN 2,100 for a couple with two children, all ensure the same level of well-being.

The OECD scales applied above have no clear connection with any economic theory. The subjective approach to equivalence scales also has no specific theory behind it. However, it is based on a very simple and intuitive idea. This approach is data driven since it is based on information about how 
people evaluate their income according to their feelings or needs; these evaluations are used to estimate a subjective scale. This is in significant contrast to the OECD expert method, which while being straightforward to use in practice, ignores a person's perception of income. However, using an individual's declaration of personal preference in the estimation of an equivalence scale may be questioned. This is because a subjective approach assumes that every respondent has the same understanding of the term "minimum income", or the verbal qualifiers such as "good income" or "bad income" and that these expressions have the same welfare or well-being associations. As stated by Kapteyn (1994), the main reason why economists have generally ignored subjective information is that “(...) most economists simply do not believe what people say. They feel that the questions asked to respondents are too difficult or abstract to yield sensible answers. Hence they cannot believe that what people say reflects preferences in the same way that observed choice behaviour does".

Despite such a commonplace view, the subjective approach has been getting wider acceptance especially among applied social science researchers. This may be, at least partly, attributed to the problems in applying the scales derived from the revealed preferences approach, which, while the most appealing theoretically, at the same time suffer from the wellknown identification problem (Pollak and Wales, 1979; Blundell and Lewbel, 1991). On the other hand, the expert scales such as the OECD ones, which are frequently used by statistical offices, are arbitrary.

However, according to Coulter et al. (1992), searching for a single "correct" equivalence scale is misguided since the scales are part of the social valuation process. This opinion is consistent with the view of Garner and Short (2003) that researchers, as well as policymakers, use the different equivalence scales as complementary rather than their substitutes. This makes us consider a subjective approach to equivalence scales as a valuable complement to the two previously mentioned methods.

We define the equivalence scale as the relative cost of achieving the level of utility $u$ by a household of composition $x$ in relation to the benchmark household of composition $b$. Following Bishop et al. (2014), we denote the expenditure required to achieve the level of utility $u$ when prices are $p$ as $C(p, u, x)$. Given the same price level $p$ for all households, the equivalence scale $D(p, u, x)$ is

$$
D(p, u, x)=\frac{C(u, x)}{C(u, b)} .
$$


There are two most popular methods in the subjective approach that are used to identify an income necessary to reach the base utility. The first one that is more often applied identifies it as the situation in which people just "make ends meet". The another one uses information from the income evaluation question (IEQ) in which a person (presumably the head of the household) declares income amounts corresponding to certain verbal qualifiers such as "very bad", "bad", "just sufficient", "sufficient", "good" or "very good".

In the first method we assume that $y_{\min }^{*}$ is the unobservable minimum income necessary to reach utility level $u_{\min }^{*}$ corresponding to the "make ends meet" statement. Thus, the equivalence scale is:

$$
D\left(p, u_{\min }^{*}, x\right)=\frac{C\left(u_{\min }^{*}, x\right)}{C\left(u_{\min }^{*}, b\right)}=\frac{y_{\text {min }}^{*}(x)}{y_{\text {min }}^{*}(b)} .
$$

In order to conclude about $y_{\min }^{*}$, it is postulated that $y_{\min }$, which is the declared level of minimum income, is related to the actual income $y$ through the monotonically increasing relation $y_{\min }=f(y ; x)$. If those with the actual income above the minimum level overestimate the true value of $y_{\min }^{*}$ and those with an income below the minimum level underestimate it, then we should observe the declarations for which $y_{\min }=y_{\min }^{*}$ in the data. This assumption is the basis for the intersection method developed in Goedhart et al. (1977).

In practice, to compute the true values $y_{\min }^{*}$, one has to assume the functional form for $f($.$) . For example, Bishop, Luo and Pan (2006), and$ Stewart (2009), use the log-linear relation as the link function. The second identification strategy assumes that households are able to evaluate their own income in terms of verbal labels and that it is possible to convert people's answers into a numerical evaluation of welfare on a bounded scale within an interval $[0,1]$. The IEQ approach assumes a log-linear relation between income $y_{i}$ and welfare $W$ in the form of $\mathrm{W}\left(\mathrm{y}_{\mathrm{i}} ; \mu_{\mathrm{i}}, \sigma_{\mathrm{i}}\right) \equiv \Phi\left(\frac{1}{\sigma_{\mathrm{i}}}\left(\log \left(\mathrm{y}_{\mathrm{i}}\right)-\mu_{\mathrm{i}}\right) ; 0 ; 1\right)$, where $\Phi($.$) is a standardized$ cumulative distribution function, $\mu_{i}$ describes the financial needs of a household $i$ and $\sigma_{i}$ is the welfare sensitivity of income. Simple transformation yields 


$$
\log \left(y_{i}(\delta)\right)=\mu_{i}+\sigma_{i} \Phi^{-1}(\delta),
$$

where $\log \left(y_{i}(\delta)\right)$ is an income associated with "welfare" $\delta$, that is a value of $\Phi\left(\frac{1}{\sigma_{\mathrm{i}}}\left(\log \left(\mathrm{y}_{\mathrm{i}}\right)-\mu_{\mathrm{i}}\right)\right)$ at $\log \left(y_{i}(\delta)\right)$. A parameter $\mu_{i}$ can be estimated from a sample mean of the declared log-incomes for each of the verbal qualifiers and may be made dependent on other variables such as household size and income:

$$
\hat{\mu}_{i}=\beta_{0}+\beta_{1} \log \left(x_{i}\right)+\beta_{2} \log \left(y_{i}\right)+\varepsilon_{i},
$$

where $\hat{\mu}_{i}=\frac{1}{k} \sum_{i=1}^{k} \ln \left(y_{i}^{d}\right)$ and $y_{i}^{d}$ are amounts declared by household $i$ corresponding to the level $d$ of IEQ (Van Praag, 1971). The variance $\sigma_{i}$ reflects how much income a household requires to change its welfare evaluation from one level to another. It may be estimated as a sample standard deviation of declared log-incomes. Both approaches - the minimum income and the IEQ - should lead to similar results about equivalence scales since we assume a log-linear relation between a measure of a base utility and the actual income $y$ in both methods. In particular, the respective functional specifications are:

$$
\ln \left(y_{\min }\right)=\alpha_{0}+\alpha_{1} \ln (x)+\alpha_{2} \ln (y)+u .
$$

and

$$
\ln (y(\delta))=\left[\beta_{0}+\beta_{1} \ln (x)+\beta_{2} \ln (y)\right]+\bar{\sigma} \Phi^{-1}(\delta)+\varepsilon .
$$

From the functions above we get $y_{\text {min }}^{*}=\exp \left(\frac{\alpha_{0}+\alpha_{1} \ln (x)}{1-\alpha_{2}}\right)$ and $y^{*}(\delta)=\exp \left(\frac{\beta_{0}+\beta_{1} \ln (x)+\bar{\sigma} \Phi^{-1}(\delta)}{1-\beta_{2}}\right)$. This gives the equivalence scales $D\left(p, u_{\min }^{*}, x\right)=\frac{y_{\min }^{*}(x)}{y_{\min }^{*}(1)}=(x)^{\frac{\alpha_{1}}{1-\alpha_{2}}} \quad$ in $\quad$ the former $\quad$ case and $D\left(p, u_{\delta}^{*}, x\right)=\frac{y^{*}(\delta, x)}{y^{*}(\delta, 1)}=(x)^{\frac{\beta_{1}}{1-\beta_{2}}}$ in the latter. For the minimum income approach the equivalence scale is defined by the ratio of income levels that 
give the same utility associated with the "make ends meet" situation. In the IEQ approach it is the ratio of the amounts that leads to the welfare level of $\delta$.

The above scales may be easily extended to a case in which an additional child influences the financial needs of a household differently to an adult. In such a case the equivalence scale for the IEQ approach will be

$$
D\left(p, u_{\delta}^{*}, x_{a}, x_{c}\right)=\frac{y^{*}\left(\delta, x_{a}, x_{c}\right)}{y^{*}(\delta, 1,0)}=\left(x_{a}\right)^{\frac{\beta_{1 a}}{1-\beta_{2}}}\left(x_{c}+1\right)^{\frac{\beta_{1 c}}{1-\beta_{2}}},
$$

where $x_{a}$ denotes the number of adults and $x_{c}$ the number of children in a household.

\section{DATA AND MODEL SPECIFICATION}

The empirical part of this paper is based on an Evaluation Income Question (IEQ) in which the head of the household declares the amounts of total monthly net income that for this household would be considered as "very bad", "insufficient", "barely sufficient", "good" and "very good". A minimum income question is not used since it is not available in the dataset.

Data used in the research are from the Polish Household Budget Survey (PHBS) for 2010. The PHBS is a countrywide survey based on a random sample of households. It is conducted every year by the Central Statistical Office (further: CSO). The total sample size is 37,412 households with 107,967 people. The analysis is restricted to 33,811 units with 104,579 people. Households that reported non-positive disposable income and those with income per capita in the first and the last centiles among those with positive income were excluded. ${ }^{2}$ Households belonging to the categories with small number of observations in the dataset such as: " $3+3$ " (a3k3), " $2+4$ " (a2k4), " $4+3$ " (a4k3) and those with 5 and more adults were also not taken into consideration.

\footnotetext{
2 The exclusion of two extreme centiles from income distribution in poverty analysis is a controversial decision. However, two arguments made us do this. Firstly, this study is based on a linear regression model that is non-robust to the existence of outliers and one can be afraid that those extreme observations do not belong the same population model as others. Secondly, the PHBS registers income only from an one month. Unusually low or high income in a month of survey may be not representative of average yearly income. Additionally, the usual argument about measurement error in the case of an income close to zero is fully valid in this case.
} 
The PHBS provides particularly detailed information on each household and its members. Recorded in the survey are personal characteristics, labour market activities, incomes from work and outside work, as well as housing conditions, expenditures and subjective evaluations of income. Households participate in the survey for one month for which income and expenditure are registered in a budget and expenditure diary. Income evaluation questions are asked at the end of the month during which the interview takes place. Asking income evaluation questions after a month of conducting a diary of income and expenditure leads to more reliable answers. This decreases a potential measurement error since misperception of income may be a result of the unawareness of all received incomes, lack of remembering or just errors in summing up all the incomes. The survey methodology is described in GUS (2011).

The amounts declared in the IEQ differ considerably for each of the evaluation levels. Declarations considered to be in the category of "very bad" range from PLN 50.00 to PLN 10,000.00 with mean at PLN 1,288.60 and median at PLN 1,000.00. Respective values for the "very good" level are significantly higher - PLN 500.00 for minimum value and PLN 50,000.00 for maximum value with PLN 5,087.80 for mean and PLN 5,000.00 for median. A large variation is also seen at the other levels, but the answers are consistent since means and medians are always higher for each subsequent level (Table 4 in Appendix). The high variability of income evaluations shows that households' perceptions of the income needs are quite heterogeneous, suggesting that the same amount of money brings different satisfaction (or welfare) for different households. This strengthens our motivation to use the subjective approach.

Childless households are the most frequent household types in the sample. The "a2k0" group account for $32.17 \%$ of observations, the "a1k0" for $19.04 \%$ while the "a3k0" for $12.52 \%$. Couples with children are observed less frequently - those with one child ("a $2 \mathrm{k} 1$ ") account for $8.57 \%$ of observations and those with two children ("a2k2") for $7.19 \%$ observations. The small share of "a $2 \mathrm{k} 2$ " households results from the definition of a dependent child used in the analysis, which treats a child as aged under 14, like it is done in the OECD equivalence scale. We use this definition in order to get comparable results with the other studies (e.g. Bishop et al. 2014). One may be interested in the sensitivity of the results to other definitions of a child. The natural alternative is the definition applied in tax and benefit rules. 


\section{EQUIVALENCE SCALES AND POVERTY INCIDENCE IN THE SUBJECTIVE APPROACH}

The unconditional mean of financial needs per person for two-adult households is higher by $31.91 \%$ than for one-person households. A third adult in a household increases the mean by an extra $15.97 \%$ making it equal to 1.53 of the value for "a $1 \mathrm{k} 0$ " household. The first child of a couple raises the mean by $19.53 \%$, while the second adds only an extra $2.87 \%$, which is a strong indication of significant economies of scale in the number of adults and in the number of children. Such economies seem considerably higher than postulated by the OECD scales.

Estimates of equations (5) and (6) are given in Table 1. The basic specification includes two explanatory variables: current disposable income and the number of household members. Current disposable income comprises income from hired work (permanent and temporary income, including also non-cash payments, sick-leave payments, severance payments and other income from work), income from a private farm in agriculture measuring the difference between the farm's production, natural consumption

Table 1

Estimation results

\begin{tabular}{c|c|c|c|c}
\hline & \multicolumn{3}{|c|}{ Financial needs model } & Insufficient \\
income
\end{tabular}

All the variables describing income and number of people in log form. Robust standard errors in parentheses. All estimates are significant on $1 \%$ level. Controls include regional variables (voivodship, town size).

Source: own calculations; PHBS 2010. 
and received supplements, and current investment in the farming production and farm-related tax; income from non-agricultural self-employment; income from property, capital income, social insurance benefits (all kinds of pension, retirement payments), other social benefits (family benefits and social assistance) and other income such as gifts, alimonies, winnings in lotteries, etc.

Controls for town size and voivodships are additionally included in the model "basic 1", while the specification "basic 2" uses different parameters for the number of adults and the number of children. The dependent variable is the financial need calculated as the log of the average from the reported income valuations. These models are compared with the cases in which the dependent variable is defined by the values of income considered to be "insufficient".

All R-squared coefficients are close to 0.6. Small differences among statistic values confirm that household size and current income are the most important predictors of a household's financial needs. There is not much difference between the financial needs approach and the minimum income approach based on "insufficient income" declarations. The financial need positively depends on the current income level. The basic specification tells us that a $1 \%$ increase in current disposable income raises the financial needs of a household by $0.49 \%$. Other models give slightly lower estimates of income elasticity but all of them are above 0.4 . Such positive preference drift means that only part of the additional income contributes to a welfare gain while the rest increases the financial needs. This makes an ex-ante income evaluation different than the ex-post appraisal. The disappointment effect among those who get what they previously declared as a desirable amount is often observed in everyday life situations.

\subsection{Subjective equivalence scales}

Table 2 compares subjective equivalence scales implied by previously discussed estimates with the OECD equivalence scales and the square root scale. We present all the subjective scales. However, we do not analyse those from the "basic model" since we consider them as derived from an excessively unrealistic model.

The subjective equivalence scales are very different from the OECD scales. The increased cost caused by a second adult is around $25-28 \%$ according to the subjective approach with the corresponding values in 
Table 2

Subjective and expert equivalence scales (HBS, 2010)

\begin{tabular}{c|c|c|c|c|c|c|c}
\hline & \multicolumn{4}{|c|}{ Subjective scales } & \multicolumn{3}{c}{ Expert scales } \\
\hline & Basic & Basic 1 & Basic 2 & $\begin{array}{c}\text { Insufficient } \\
\text { income }\end{array}$ & $\begin{array}{c}\text { OECD } \\
\text { (modified) }\end{array}$ & $\begin{array}{c}\text { OECD } \\
\text { (old) }\end{array}$ & $\begin{array}{c}\text { Square } \\
\text { root }\end{array}$ \\
\hline $\mathrm{a} 1 \mathrm{k} 0$ & 1.00 & 1.00 & 1.00 & 1.00 & 1.00 & 1.00 & 1.00 \\
\hline $\mathrm{a} 1 \mathrm{k} 1$ & 1.21 & 1.26 & 1.11 & 1.09 & 1.30 & 1.50 & 1.41 \\
\hline $\mathrm{a} 2 \mathrm{k} 0$ & 1.21 & 1.26 & 1.28 & 1.25 & 1.50 & 1.70 & 1.41 \\
\hline $\mathrm{a} 2 \mathrm{k} 1$ & 1.35 & 1.45 & 1.41 & 1.37 & 1.80 & 2.20 & 1.73 \\
\hline $\mathrm{a} 2 \mathrm{k} 2$ & 1.45 & 1.60 & 1.50 & 1.45 & 2.10 & 2.70 & 2.00 \\
\hline $\mathrm{a} 2 \mathrm{k} 3$ & 1.54 & 1.72 & 1.56 & 1.50 & 2.40 & 3.20 & 2.24 \\
\hline $\mathrm{a} 3 \mathrm{k} 0$ & 1.35 & 1.45 & 1.48 & 1.43 & 2.00 & 2.40 & 1.73 \\
\hline $\mathrm{a} 3 \mathrm{k} 1$ & 1.45 & 1.60 & 1.63 & 1.57 & 2.30 & 2.90 & 2.00 \\
\hline $\mathrm{a} 3 \mathrm{k} 2$ & 1.54 & 1.72 & 1.73 & 1.65 & 2.60 & 3.40 & 2.24 \\
\hline $\mathrm{a} 4 \mathrm{k} 0$ & 1.45 & 1.60 & 1.64 & 1.57 & 2.50 & 3.10 & 2.00 \\
\hline $\mathrm{a} 4 \mathrm{k} 1$ & 1.54 & 1.72 & 1.81 & 1.72 & 2.80 & 3.60 & 2.24 \\
\hline $\mathrm{a} 4 \mathrm{k} 2$ & 1.62 & 1.83 & 1.91 & 1.81 & 3.10 & 4.10 & 2.45 \\
\hline
\end{tabular}

Source: own calculations based on 33,811 households out of 37,412 in PHBS 2010.

OECD approach of $50 \%$ or $70 \%$. Comparing these estimates with those by Bishop et al. (2014) reveals similarities with the values in Italy (28\%), Finland (20\%) and Belgium (21\%). The cost associated with the third person is in the range of $18-20 \%$, while for a fourth person it would be in the range of $14-16 \%$, which shows that the marginal cost caused by each consecutive adult is decreasing. These makes our results similar to the estimates given by Bishop et al. (2014) for the euro-zone countries. However, our estimates of subjective costs of children are lower than those reported there. The marginal cost of a first child for a couple is about $12-13 \%$. The countries with the most similar results are Germany (17\%) and the Netherlands (15\%) but the average for all the euro-zone countries is much higher $-30 \%$. The marginal cost of a second child for a couple is $7-9 \%$. This range is more often observed in the euro zone, for example the estimate for France was 7\% and for Austria $6 \%$.

The results presented in Table 2 confirm that the subjective approach yields larger economies of scale in a household than postulated in the OECD method. Also, the decreasing marginal cost of an additional child suggested by the subjective scales should be noticed since the OECD scales simply assume the constant change. 


\subsection{Poverty rates}

Different equivalence scales lead to different poverty measures (Table 3). Replacing the OECD scale by a subjective one results in a smaller number of people living in households below the poverty line. However, the difference is not very large: the overall subjective rate for PHBS2010 is $12.58 \%$, and $14.56 \%$ when the modified OECD scale is applied. The estimate with the square root form of the scale, $13.51 \%$, lies in the middle.

Table 3

Poverty incidence 2010 by household biological type (\%)

\begin{tabular}{l|r|r|r|r|r|r}
\hline & \multicolumn{3}{|c|}{ Subjective approach } & \multicolumn{2}{c}{ Expert approach } \\
\hline & Basic & Basic 1 & Basic 2 & $\begin{array}{c}\text { Insufficient } \\
\text { income }\end{array}$ & $\begin{array}{c}\text { OECD } \\
\text { (modified) }\end{array}$ & $\begin{array}{c}\text { Square } \\
\text { root form }\end{array}$ \\
\hline Individual rate & 12.58 & 12.54 & 12.44 & 12.40 & 14.56 & 13.51 \\
\hline a1k0 & 28.02 & 25.17 & 25.13 & 26.01 & 14.12 & 18.20 \\
\hline a1k1 & 25.96 & 25.06 & 14.70 & 15.84 & 13.02 & 22.27 \\
\hline a2k0 & 10.97 & 10.49 & 10.85 & 10.99 & 8.74 & 9.50 \\
\hline a2k1 & 9.29 & 9.55 & 9.07 & 8.95 & 9.55 & 10.81 \\
\hline a2k2 & 9.65 & 10.71 & 8.64 & 8.42 & 13.87 & 15.20 \\
\hline a2k3 & 15.86 & 16.71 & 12.57 & 12.57 & 25.36 & 25.50 \\
\hline a3k0 & 8.93 & 9.33 & 10.05 & 9.78 & 13.37 & 11.10 \\
\hline a3k1 & 8.92 & 9.75 & 10.49 & 9.91 & 16.13 & 13.19 \\
\hline a3k2 & 10.14 & 12.08 & 12.08 & 11.18 & 22.94 & 18.06 \\
\hline a4k0 & 7.36 & 8.08 & 8.62 & 8.19 & 15.76 & 10.48 \\
\hline a4k1 & 8.19 & 10.00 & 11.67 & 11.02 & 22.61 & 14.43 \\
\hline a4k2 & 6.54 & 7.20 & 8.92 & 7.43 & 25.06 & 13.86 \\
\hline
\end{tabular}

Source: own calculations based on 33,811 households out of 37,412 in PHBS 2010.

Notes: The poverty lines are calculated as $60 \%$ of the median equivalent income.

The rate for single-person households is $14.12 \%$ for the modified OECD scale and above $25 \%$ for the subjective approach. The subjective rate is also higher for a couple without children but in this group the difference with the expert method is not so profound. The two approaches bring the most similar results for "a1k1" and "a2k1". The results become more divergent as the number of people in household increases. For a couple with three children ("a2k3"), the OECD approach gives the "at-risk" of poverty rate as $25.50 \%$, 
while with the subjective rate it is in the range of $12-16 \%$. For the "a $4 \mathrm{k} 0$ ", the rates using the two approaches are $15.76 \%$ and around $8.0 \%$, respectively.

Poverty calculated using the subjective approach is higher than that calculated using the OECD approach when the number of households, instead of the number of people, below the poverty line is considered. This happens because the larger economies of scale improve the relative position of large households in relation to small units in the "well-being" distribution.

\section{CONCLUSIONS}

The subjective equivalence scales for Poland in 2010 were estimated in the paper. Subjective thresholds are assumed to reflect the amount of economic resources that households of different sizes require to reach the same level of well-being. The literature on subjective-based measures has been growing quickly in the last two decades, but the evidence for Central European countries is limited.

Our subjective equivalence scales for Poland increase with household size and show larger economies of scale when comparing them with the OECD scales. These results are consistent with other studies such as Buchmann et al. (1988) and Bishop et al. (2014). The subjective scales allow us to conclude about the declining marginal cost of a child, in that we find adding the first child to be more expensive than adding a second one. This suggests a positive fixed cost of having children that is not considered in the OECD scale.

Additionally, we found that the first child for a couple adds more to the costs than a third adult. This is the opposite relation to the one identified in Bishop et al. (2014) for the euro-zone countries where a third adult added lower costs than a first child.

Replacing the OECD scale by the subjective scales reduces the overall poverty rate calculated as the number of individuals living in households below the poverty line. On the other hand, the rate is greater if the number of households is considered. This is caused by the flatter shape of subjective equivalence scales that worsen small households' position in the "wellbeing" distribution in relation to large ones. As a result, the subjective approach indicates one-person households as being most vulnerable to financial hardship while the official statistics based on the OECD scales point to large families as those who are in the worst financial position.

The results based on subjective data lead to different policy recommendations than those postulated on the basis of the official statistics. 
This approach would ask for taking the fixed costs of raising children into consideration when designing child support policies and paying more attention to small households. Taking subjective information into consideration in designing social policy is currently not particularly popular. However, there are well-known economists among the proponents of doing this (Layard 2006; Stiglitz, Sen and Fittoussi 2009).

\section{REFERENCES}

Bishop, J., A., Grodner, A., Liu, H., Ahamdanech-Zarco I., Subjective Poverty Equivalence Scales for Euro Zone Countries, "The Journal of Economic Inequality", vol. 12, no. 2, pp. 265-278, 2014.

Bishop, J., A., Luo, F., Pan, X., Economic Transition and Subjective Poverty in Urban China, "Review of Income and Wealth", vol. 52, no. 4, pp. 625-641, 2006.

Blundell, R., Lewbel, A., The Information Content of Equivalence Scales, "Journal of Econometrics", vol. 50, issue 1-2, pp. 49-68, 1991.

Bollinger, Ch. R., Cheti, N., Pudney S., Two Can Live as Cheaply as One... But Three's a Crowd, University of Essex, series: ISER Working Paper Series, no. 10/2012, 2012.

Buhmann, B., Rainwater, L., Smeeding, T. M., Equivalence Scales, Well-Being, Inequality and Poverty: Sensitivity Estimates Across Ten Countries Using the Luxemburg Income Study (LIS) Database", "Review of Income and Wealth", vol. 34, no. 2, pp. 115-142, 1988.

Coulter, F. A. E., Cowell, F. A., Jenkins, S. P., Differences in Needs and Assessment of Income Distributions, "Bulletin of Economic Research", vol. 44, no. 2, pp. 77-124, 1992.

de Ree, J., Alessiez, R., Pradhanx, M., The Price and Utility Dependence of Equivalence Scales: Evidence from Indonesia, "Journal of Public Economics", vol. 97, pp. 272-281, 2013.

Dudek, H., Statystyczna analiza subiektywnej oceny dochodów gospodarstw domowych rolników [The Statisitical Analysis of Subjective Assessment of Income Obtained by Farmers' Household], "Roczniki Nauk Rolniczych", series G 96 (4), pp. 41-49, 2009.

Dudek, H., Subiektywne skale ekwiwalentności - Analiza na podstawie danych o satysfakcji z osiaganych dochodów [Subjective Equivalence Scales - Analysis Based on Data on Satisfaction with income Earned], "Research Papers of Wrocław University of Economics", no. 242, pp. 153-162, 2012.

Dudek, H., Landmesser, J., Income Satisfaction and Relative Deprivation ,"Statistics in Transition", 13(2), pp. 321-334, 2012.

Eurostat, Combating Poverty and Social Exclusion: A Statistical Portrait of the European Union 2010, Luxemburg: European Union, 2010.

Garner, T. I., Short, K. S., Personal Assessments of Minimum Income and Expenses: What Do They Tell Us about 'Minimum Living' Thresholds and Equivalence Scales? [in:] Bishop, J. A., Amiel, Y., (eds.) Inequality, Welfare and Poverty: Theory and Measurement, Research on Economic Inequality, pp. 191-243. Elsevier Science, 2003. 
Goedhart, T., Halberstadt, V., Kepteyn, A., van Praag, B., The Poverty Line: Concept and Measurement, "Journal of Human Resources", vol. 12, no. 4, pp. 503-520, 1977.

GUS, Metodologia badania budżetów gospodarstw domowych [Methodology for Household Budgets Survey]. Central Statistical Office, Warsaw, 2011.

Kapteyn, A., The Measurement of Household Cost Functions. Revealed Preference versus Subjective Measures, "Journal of Population Economics", vol. 7, no. 4, pp. 333-350, 1994.

Layard, R., Happiness and Public Policy: A Challenge to the Profession, "The Economic Journal", no. 116, pp. 24-33, 2006.

Lewbel, A., Pendakur, K., Equivalnence Scales [in:] Durlauf, S. N., Blume, L. (eds.) The New Palgrave Dictionary of Economics, pp. 1-9. Palgrave Macmillan, 2008.

Podgórski, J., Zastosowanie metody "Leyden Poverty Line" w warunkach Polski, [Application of the "Leyden Poverty Line" in Poland], "Wiadomości Statystyczne", no.11, pp. 5-9, 1990.

Podgórski, J., Subiektywne linie ubóstwa - nowe wyniki [Subjective Lines of Poverty - New Results], "Wiadomości Statystyczne", no. 11, pp. 6-12, 1991.

Podgórski, J., Metody wyznaczania subiektywnych linii ubóstwa [Methods of Determining Subjective Lines of Poverty], "Wiadomości Statystyczne", no. 12, pp. 12-19, 1994.

Pollak, R. A., Wales, T. J., Welfare Comparisons and Equivalence Scales, "American Economic Review", vol. 69, no. 2, pp. 216-221, 1979.

Stewart, M., The Estimation Of Pensioner Equivalence Scales Using Subjective Data, "Review of Income and Wealth", vol. 55, no. 4, pp. 907-929, 2009.

Stiglitz, J., Sen, A., Fitoussi, J-E, Report by the Commission on the Measurement of Economic Performance and Social Progress, the Commission on the Measurement of Economic Performance and Social Progress, Paris, 2009.

Ulman, P., Equivalence Scale in Terms of Polish Households' Source of Income, "Folia Oeconomica Stetinesia", no. 10 (18), Wydawnictwo Naukowe Uniwersytetu Szczecińskiego [the University of Szczecin Press], 2012.

Van Praag, B., The Welfare Function of Income in Belgium: An Empirical Investigation, "European Economic Review", vol. 11, no. 3, pp. 337-369, 1971. 


\section{APPENDIX}

Table 4

Summary statistics for Income Evaluation Question (2010, in PLN)

\begin{tabular}{l|r|r|r|r|r|r}
\hline & $\begin{array}{c}\text { Financial } \\
\text { needs }\end{array}$ & Very bad & Insufficient & $\begin{array}{c}\text { Just } \\
\text { sufficient }\end{array}$ & \multicolumn{1}{c}{ Good } & Very good \\
\hline min & 163.86 & 50.00 & 100.00 & 270.00 & 300.00 & 500.00 \\
\hline med. & 1083.77 & 1000.00 & 1500.00 & 2000.00 & 3000.00 & 5000.00 \\
\hline mean & 1208.61 & 1288.59 & 1725.32 & 2250.55 & 3542.15 & 5087.81 \\
\hline max & 10627.39 & 8000.00 & 10000.00 & 15000.00 & 25000.00 & 50000.00 \\
\hline $\mathrm{n}$ & 33811 & 33811 & 33811 & 33811 & 33811 & 33811 \\
\hline
\end{tabular}

Source: own calculations based on 33,811 households out of 37,412 in PHBS 2010.

Table 5

Summary statistics for Income Evaluation Question (2010, in PLN) by household types

\begin{tabular}{|c|c|c|c|c|c|c|c|}
\hline & & $\begin{array}{c}\text { Financial } \\
\text { needs }\end{array}$ & Very bad & Insufficient & $\begin{array}{c}\text { Just } \\
\text { sufficient }\end{array}$ & Good & Very good \\
\hline 1 & 2 & 3 & 4 & 5 & 6 & 7 & 8 \\
\hline \multirow{5}{*}{$\mathrm{a} 1 \mathrm{k} 0$} & $\min$ & 314.5 & 50.0 & 100.0 & 270.0 & 300.0 & 500.0 \\
\hline & med. & 1812.3 & 1000.0 & 1200.0 & 1500.0 & 2500.0 & 3300.0 \\
\hline & mean & 1974.9 & 974.4 & 1292.9 & 1666.2 & 2626.1 & 3881.5 \\
\hline & $\max$ & 10627.4 & 5000.0 & 7000.0 & 8500.0 & 15000.0 & 25000.0 \\
\hline & $\mathrm{n}$ & 2688.0 & 2688.0 & 2688.0 & 2688.0 & 2688.0 & 2688.0 \\
\hline \multirow{5}{*}{ a1k1 } & $\min$ & 335.8 & 100.0 & 300.0 & 500.0 & 1000.0 & 1500.0 \\
\hline & med. & 1084.4 & 1000.0 & 1500.0 & 1900.0 & 3000.0 & 4000.0 \\
\hline & mean & 1160.5 & 1119.8 & 1520.4 & 1985.5 & 3141.3 & 4551.1 \\
\hline & $\max$ & 2883.5 & 3000.0 & 4000.0 & 5000.0 & 10000.0 & 20000.0 \\
\hline & $\mathrm{n}$ & 337.0 & 337.0 & 337.0 & 337.0 & 337.0 & 337.0 \\
\hline \multirow{5}{*}{$\mathrm{a} 2 \mathrm{k} 0$} & $\min$ & 283.9 & 100.0 & 200.0 & 450.0 & 700.0 & 1000.0 \\
\hline & med. & 1219.0 & 1000.0 & 1500.0 & 2000.0 & 3000.0 & 4500.0 \\
\hline & mean & 1302.6 & 1272.8 & 1707.6 & 2230.2 & 3503.1 & 5020.8 \\
\hline & $\max$ & 6758.1 & 7000.0 & 9900.0 & 10000.0 & 20000.0 & 50000.0 \\
\hline & $\mathrm{n}$ & 10523.0 & 10523.0 & 10523.0 & 10523.0 & 10523.0 & 10523.0 \\
\hline \multirow{5}{*}{$\mathrm{a} 2 \mathrm{k} 1$} & $\min$ & 263.7 & 100.0 & 400.0 & 500.0 & 1000.0 & 1500.0 \\
\hline & med. & 961.2 & 1500.0 & 2000.0 & 2500.0 & 4000.0 & 5000.0 \\
\hline & mean & 1038.0 & 1500.8 & 2020.5 & 2643.9 & 4227.4 & 6184.4 \\
\hline & $\max$ & 3758.5 & 6000.0 & 7000.0 & 10000.0 & 20000.0 & 45000.0 \\
\hline & $\mathrm{n}$ & 2899.0 & 2899.0 & 2899.0 & 2899.0 & 2899.0 & 2899.0 \\
\hline \multirow{5}{*}{ a2k2 } & $\min$ & 176.4 & 100.0 & 400.0 & 600.0 & 800.0 & 1200.0 \\
\hline & med. & 740.4 & 1500.0 & 2000.0 & 2500.0 & 4000.0 & 5500.0 \\
\hline & mean & 800.8 & 1551.0 & 2088.6 & 2743.8 & 4319.4 & 6242.4 \\
\hline & $\max$ & 3152.7 & 6000.0 & 8000.0 & 10000.0 & 20000.0 & 40000.0 \\
\hline & $\mathrm{n}$ & 2431.0 & 2431.0 & 2431.0 & 2431.0 & 2431.0 & 2431.0 \\
\hline
\end{tabular}




\begin{tabular}{|c|c|c|c|c|c|c|c|}
\hline 1 & 2 & 3 & 4 & 5 & 6 & 7 & 8 \\
\hline \multirow{5}{*}{$\mathrm{a} 2 \mathrm{k} 3$} & $\min$ & 172.6 & 400.0 & 500.0 & 700.0 & 1000.0 & 1500.0 \\
\hline & med. & 565.3 & 1500.0 & 2000.0 & 2500.0 & 4000.0 & 5000.0 \\
\hline & mean & 593.8 & 1436.2 & 1931.4 & 2562.3 & 3989.5 & 5727.5 \\
\hline & $\max$ & 1634.5 & 4000.0 & 5000.0 & 8000.0 & 12000.0 & 25000.0 \\
\hline & $\mathrm{n}$ & 547.0 & 547.0 & 547.0 & 547.0 & 547.0 & 547.0 \\
\hline \multirow{5}{*}{$\mathrm{a} 3 \mathrm{k} 0$} & $\min$ & 175.9 & 100.0 & 180.0 & 500.0 & 700.0 & 1000.0 \\
\hline & med. & 944.1 & 1500.0 & 2000.0 & 2500.0 & 4000.0 & 5000.0 \\
\hline & mean & 1007.1 & 1466.5 & 1974.3 & 2591.3 & 4093.2 & 5846.4 \\
\hline & $\max$ & 5378.4 & 6000.0 & 8000.0 & 15000.0 & 25000.0 & 50000.0 \\
\hline & $\mathrm{n}$ & 4234.0 & 4234.0 & 4234.0 & 4234.0 & 4234.0 & 4234.0 \\
\hline \multirow{5}{*}{$\mathrm{a} 3 \mathrm{k} 1$} & $\min$ & 207.0 & 100.0 & 400.0 & 610.0 & 1000.0 & 1500.0 \\
\hline & med. & 735.9 & 1500.0 & 2000.0 & 2500.0 & 4000.0 & 5500.0 \\
\hline & mean & 781.1 & 1505.0 & 2035.8 & 2669.5 & 4240.9 & 6108.1 \\
\hline & $\max$ & 2687.4 & 6000.0 & 6500.0 & 8000.0 & 15000.0 & 30000.0 \\
\hline & $\mathrm{n}$ & 1626.0 & 1626.0 & 1626.0 & 1626.0 & 1626.0 & 1626.0 \\
\hline \multirow{5}{*}{$\mathrm{a} 3 \mathrm{k} 2$} & $\min$ & 194.6 & 200.0 & 500.0 & 800.0 & 1400.0 & 2000.0 \\
\hline & med. & 592.3 & 1500.0 & 2000.0 & 2500.0 & 4000.0 & 5500.0 \\
\hline & mean & 630.0 & 1520.2 & 2058.5 & 2701.6 & 4292.2 & 6100.0 \\
\hline & $\max$ & 1600.4 & 4000.0 & 5000.0 & 8000.0 & 12000.0 & 20000.0 \\
\hline & $\mathrm{n}$ & 637.0 & 637.0 & 637.0 & 637.0 & 637.0 & 637.0 \\
\hline \multirow{5}{*}{$\mathrm{a} 4 \mathrm{k} 0$} & $\min$ & 243.4 & 100.0 & 450.0 & 500.0 & 1200.0 & 1500.0 \\
\hline & med. & 772.6 & 1500.0 & 2000.0 & 2500.0 & 4000.0 & 6000.0 \\
\hline & mean & 827.7 & 1592.5 & 2159.4 & 2821.5 & 4514.4 & 6476.4 \\
\hline & $\max$ & 3300.4 & 8000.0 & 10000.0 & 11000.0 & 15000.0 & 30000.0 \\
\hline & $\mathrm{n}$ & 2417.0 & 2417.0 & 2417.0 & 2417.0 & 2417.0 & 2417.0 \\
\hline \multirow{5}{*}{$\mathrm{a} 4 \mathrm{k} 1$} & $\min$ & 198.2 & 100.0 & 500.0 & 700.0 & 1500.0 & 2000.0 \\
\hline & med. & 614.3 & 1500.0 & 2000.0 & 2600.0 & 4000.0 & 6000.0 \\
\hline & mean & 654.9 & 1585.5 & 2129.9 & 2818.3 & 4457.0 & 6305.7 \\
\hline & $\max$ & 2036.1 & 5000.0 & 8000.0 & 10000.0 & 15000.0 & 25000.0 \\
\hline & $\mathrm{n}$ & 983.0 & 983.0 & 983.0 & 983.0 & 983.0 & 983.0 \\
\hline \multirow{4}{*}{$\mathrm{a} 4 \mathrm{k} 2$} & $\min$ & 163.9 & 100.0 & 700.0 & 900.0 & 1200.0 & 1600.0 \\
\hline & med. & 530.9 & 1500.0 & 2000.0 & 2800.0 & 4000.0 & 6000.0 \\
\hline & mean & 569.2 & 1654.8 & 2247.3 & 3002.4 & 4588.4 & 6408.8 \\
\hline & $\mathrm{n}$ & 387 & 387 & 387 & 387 & 387 & 387 \\
\hline \multirow{5}{*}{ Total } & $\min$ & 163.9 & 50.0 & 100.0 & 270.0 & 300.0 & 500.0 \\
\hline & med. & 1083.8 & 1000.0 & 1500.0 & 2000.0 & 3000.0 & 5000.0 \\
\hline & mean & 1208.6 & 1288.6 & 1725.3 & 2250.6 & 3542.1 & 5087.8 \\
\hline & $\max$ & 10627.4 & 8000.0 & 10000.0 & 15000.0 & 25000.0 & 50000.0 \\
\hline & $\mathrm{n}$ & 33811.0 & 33811.0 & 33811.0 & 33811.0 & 33811.0 & 33811.0 \\
\hline
\end{tabular}

Source: own calculations based on 33,811 households out of 37,412 in PHBS 2010. 